

\title{
INFLUENCE OF RISK MANAGEMENT ON SUPPLY CHAIN PROJECTS IN KENYA - A CASE OF DELOITTE KENYA
}

\author{
${ }^{1 *}$ Omuombo Arthur Ngaji, \\ ${ }^{1}$ Post Graduate Student, Jomo Kenyatta University of Agriculture and Technology \\ ${ }^{2}$ Dr, John Achuora,
}

Lecturer, Jomo Kenyatta University of Agriculture and Technology

P. O. Box 62000, 00200 Nairobi, Kenya

* Corresponding Author Email: omuomboarthurg@gmail.com

\begin{abstract}
Purpose: This study examined the Influence of Risk Management on Supply Chain Projects in Kenya. Risk Management is a critical issue in the industry. The study sought to assess Influence of Risk Management on Supply Chain Projects in Kenya.

Methodology: The study adopted a descriptive survey design. The target population of the study was all the completed (566) Supply Chain Projects in Deloitte within the 2013 to 2017 strategic year period. The study used self-structured questionnaires to collect primary data from respondents and the data collected was cleaned, pretested, validated, coded, summarized and analysed using statistical package of SPSS V23. The study findings were presented using bar charts and pie charts.
\end{abstract}

Results: The study found that the project managers had conceptual skills, technical skills, cost management skills, which positively influence Risk Management of supply chain projects. In addition, the study established that technological literacy and awareness, projects tools and equipment, skilled manpower, manpower training capacity, technological innovation, analytical and computational capacity and project team's knowledge on ICT influence Risk Management in supply chain projects. Further, the study found that schedule development, schedule crashing, schedule compression, sequence of activities and schedule fast tracking influence Risk Management in supply chain projects. Also, the study found that factors such as the GDP cost of relocation of public utilities, inflation rates, variation of cost of labor, equipment hire rates, government debt service ratio, competing demands for government funds and unemployment rates influence Risk Management in supply chain projects.

Contribution to policy and practice: Based on the study findings, the study concludes that risk planning influences Supply Chain Projects. The study also recommends that the government of Kenya should revise the current monitory policy governing inflation rates and foreign exchange rates so as to ensure the stability of foreign exchange rates and reduction in inflation rate.

Keywords: Risk Planning, Risk Response, Risk monitoring, Risk Assessment 
International Journal of Supply Chain and

Logistics ISSN 2520-3983 (online)

Vol 3, Issue 3, pp 1 - 23, 2019

www.carijournals.org

\subsection{INTRODUCTION}

\subsection{Background of the Study}

According to World Bank (2010), conflict, poor workmanship and incompetence of contractors are among the factors influencing Supply Chain Projects. According to the United Nations Relief and Works Agency (UNRWA, 2014), many local projects report poor Risk Management due to: unavailability of materials; excessive amendments of design and drawings; poor coordination among participants, ineffective monitoring and feedback, and lack of project leadership skills and regional conflicts.

Magutu et al. (2013) points out that a number of factors that are influenced by the clients and can influences the Risk Management of work were found to include; design changes, stoppages due to disputes between contractors and clients, stoppages because of insolvency, lack of adherence to regulatory requirements, and inspection delays. Many though think that the initial planning done by the client and the consultants determines the future direction (World Bank, 2013). Performance is about how well something can be done and to measure Supply Chain Projects, a number of performance indicators such as time, cost, quality, client satisfaction, business performance, functionality, profitability, health and safety (Cheung, Wong and Pang, 2015) have to be considered. To establish the performance factors, Supply Chain Projects has been widely considered by many scholars as an indicator of good performance where the planned cost translates to the actual cost (Kenya Engineer, 2015).

\subsubsection{Global Perspective}

Globally numerous researches have been carried out all pointing to the fact that the industry has performance problems in both developing and the developed countries. A study by Apolot, Alinaitwe and Tindiwensi (2006) identifies parameters to measure industry performance which include: the economic performance indicators, quality performance indicators; environmental and informal sector performance indicators.

\subsubsection{Regional Perspective}

Most projects at some point within the project life cycle need to acquire some resources and materials from outside suppliers and at the end deliver the output of the project to the customers. This entire cycle is referred to as the project Supply Chain (SC). Supply chain is a system of organizations, people, activities, information, and resources involved in moving a product or service from supplier to end customer (WEF, 2012). It encompasses key processes of purchasing, manufacturing, warehousing, transportation, customer service, demand planning, and supply planning. The key objectives of supply chain in projects are to ensure that customer requirements are met, ensure that appropriate cost saving margins are maintained and quality is optimized. All these objectives are geared towards enhancing shareholders value in the project.

\subsubsection{Local Perspective}

In Kenya, supply chain is the predominant mode of transport accounting for 93 percent of all freight and passenger traffic in Kenya, but costs are high (Kenya Engineer, 2010). The supply chain sub-sector is relatively large, with a total classified network of 160,886 km (of which 11,197 $\mathrm{km}$ are paved and 149,689 $\mathrm{km}$ are gravel or earth) and over $60,000 \mathrm{~km}$ of unclassified community supply chains (Kenya Supply chains Board, 2012). This provides all-weather network of supply chains in the densely-populated parts of the country and some limited access in the rest of the 
country. Unlike the neighboring countries which have major areas without all-weather supply chains, the key challenge for Kenya is to bring the network in poor condition (56 percent) to good condition (currently just 11 percent), while ensuring that adequate maintenance is carried out on the rest (Deloitte Annual Report, 2013).

\subsection{Problem Statement}

According to World Bank more than $80 \%$ of organizations indicate that SCRM has become a greater priority in their organization over the last five years and $80 \%$ of companies worldwide see better protection of supply chains as a priority (WEF, 2012). Literature reviews in this study shows that adequate SCRM contributes to gross domestic product (GDP) by more than $70 \%$ yet there is little or no empirical evidence available to this study on the impact of risk management in supply chain performance (El-Kot \& Lean, 2008).

According to a World Economic Forum report 2012, supply chains have become longer and more complex, while the severity and frequency of supply chain disruptions seems to be increasing. Significant supply chain disruptions reduce the share price of affected companies by as much as $7 \%$ on average (WEF, 2012). A study by Zurich Global Corporate North America done in conjunction with the Business Continuity Institute, found that $70 \%$ of the companies had undergone some kind of business risk disruption. The data indicates that $40 \%$ of the companies that experience a supply chain risk disruption of more than a year do not recover. This therefore impacts negatively on supply chain performance (ZGC, 2010).

Despite the apparent significance of SCRM and the large number of published studies on the subject, the academic literature lacks a systematic review of SCRM research. Although the SCRM growing popularity, attempts to synthesize research within this field have seldom been conducted. Aiming to fulfill part of this gap, this research paper presents a systematic review of the literature on SCRM. The research is restricted to literature published within the last 10 years (between 2004 and 2014). This paper seeks to unearth the impact of risk management in supply chain management projects. The main risk management factors to be examined include; risk planning, risk assessment, risk response and risk monitoring. The key issues discussed include a theoretical review on SCRM and the empirical study on the effect of risk management process on supply chain performance (AFDB, 2014). The problem of poor Risk Management is not only influencing the Supply Chain Projects but also the industry (Deloitte Annual Report, 2015).

Despite reliable funding by the Government based on the projected budgets, the total improved supply chain network was far below the planned output as a result of the budgets being exhausted before achieving the planed network (Deloitte Annual Report, 2016).

A study carried out by Kenya Supply chains Board indicates that in the financial years 2013/14 and 2014/15 the Government of Kenya allocated Ksh25 billion and Ksh30 billion respectively for the of 300 and 375, kilometers of new supply chains respectively (Deloitte Annual Report, 2016). However, Deloitte realized a total of 245 kilometers against a target of 300 for the 2013/14 financial year, and in 2014/2015 financial year, a total of 298 kilometers were completed against a target of 375 .. The percentage reduction in both financial years translates to $81 \%$ and $79 \%$ respectively. (Deloitte Annual Report, 2016). In the supply chain sub-sector, the extent of poor Risk Management in the overall supply chain sector portfolio remains high. As at February 2012, 200 on-going projects out of a total of 207 showed poor Risk Management, resulting in additional expenditure of Kshs. 7 billion (World Bank, 2013). 
Although the Government of Kenya continues to train both the public sector and contractor's staff, on technical, managerial and leadership skills, Risk Management in Government financed projects remains poor. Despite numerous studies done, a gap still remains, this being the reason why this study needed to be carried out. Therefore, this study focused on the Influence of Risk Management on Supply Chain Projects in Kenya.

\subsection{Objectives of the Study}

i. To assess how Risk Planning influences Supply Chain Projects within Deloitte Kenya.

ii. To establish how Risk assessment influences Supply Chain Projects within Deloitte Kenya.

iii. To determine how Risk Response influences Supply Chain Projects within Deloitte Kenya.

iv. To examine how Risk monitoring influences Supply Chain Projects within Deloitte Kenya.

\subsection{LITERATURE REVIEW}

\subsection{Theoretical review}

\subsubsection{Michael Porter's Value Chain Theory}

Lean is a functional model which basically discounts the value of economies of scale and focuses Michael Porter introduced the concept of "value chain" in his renowned book "Competitive Advantage: Creating and Sustaining superior Performance" (1985). Porter argued that the value chain analysis describes the activities the organization performs and links them to the organizations competitive position. According to Porter, value chain analysis describes the activities within and around an organization, and relates them to an analysis of the competitive strength of the organization. Therefore, it evaluates which value each particular activity adds to the organizations products or services. This idea was built upon the insight that an organization is more than a random compilation of machinery, equipment, people and money and only if these things are arranged into systems and systematic activates it will become possible to produce something for which customers are willing to pay a price. Porter argues that the ability to perform particular activities and to manage the linkages between these activities is a source of competitive advantage.

Porter distinguishes between primary activities and support activities. Primary activities are directly concerned with the creation or delivery of a product or service. They can be grouped into five main areas: inbound logistics, operations, and outbound logistics, sales and marketing, and servicing. Each of these primary activities is linked to support activities which help to improve their effectiveness or efficiency. There are four main areas of support activities which include: procurement, product and technology development, human resource management, and infrastructure (systems for planning, finance, quality, information management etc.)

\subsection{Risk Planning}

Project Competence is a set of defined behaviors that provide a structured guide enabling the identification, evaluation and development of the behaviors in individual employees (Chan and Mohan 2009). Competencies are also what people need to be successful in their jobs. Job competencies are not the same as job task. Competencies include all the related knowledge, skills, abilities, and attributes that form a person's job. This set of context-specific qualities is correlated with superior job performance and can be used as a standard against which to measure job performance as well as to develop, recruit, and hire employees.. 


\subsection{Risk Assessment}

According to Perzyk (2012) case study in foundry industry by, Pareto chart shows that the foundry staff should concentrate on reducing defects like 'sand inclusions' and 'gas holes', which make up $72 \%$ of all defects. Pareto diagrams can therefore be particularly useful in defining the targets. Pareto charts show the most frequently occurring factors and help to make the best use of limited resources by pointing at the most important problems to analyze.

Chandna and Chandra (2009) studied forging operation that produce six cylinder crankshafts used in trucks and buses. With the help of Pareto diagrams critical areas are identified and forging defects of crankshaft have been prioritized by arranging them in decreasing order of importance. Then Cause and Effect Diagram (CED) is applied to explore possible causes of defects through brain storming session and to determine the causes, which have the greatest effect. The corrective measures reduce the rejection rate from $2.43 \%$ to $0.21 \%$.

Khekalei et al., (2010) presented another case of wastage reduction in a belt manufacturing industry located in the Virabha, India which produces world class automotive belts and hoses. The main raw material for producing this automotive belt is rubber. Others raw materials are biased fabric and cord. From many years consumption of raw material was not taken seriously as rubber is reusable. But other raw material that is biased fabric and cord consumption was increased drastically which resulted in increased in the production cost of belt and reduced profit margin.

\subsection{Risk Response}

Ellis and Thomas (2000) notes that the cost of Supply Chain Projects at completion is influenced by a variety of factors both external to internal. Completion of a project within budget stipulated at the tender award stage is a universally accepted measure of project success. Most projects start to incur costs before they eventually commence (Samasian \& soon, 2007).

\subsection{Risk monitoring}

Modern highways and infrastructure projects are normally costly and require major financing for smooth operations. Despite these costs, donors are always willing to step-in for long term gain. The African Development Bank (AFDB) financed the first two phases of the Nairobi Thika Highway from Nairobi City Centre to Kenyatta University at a cost of 14 billion Kenya Shillings. The government of Kenya also gave KSh3 billion. The third phase from Kenyatta University to Thika town was financed by the Chinese government. Approximately 32Billion will have been used by the time it is completed. The operation and maintenance costs for this project are also going to be high given the size of the project (The Centre for Sustainable Urban Development, 2012). 


\subsection{Conceptual framework}

Risk Planning

- Risk Identification

- Continency Planning

- Supply Chain

Disruption

- Loss Mitigation
Risk Assessment

- Vulnerability

- Criticality

- Cost

- Frequency

\section{Risk Response}

- Risk Mitigation

- Risk Transfer

- Risk Avoidance

- Risk Acceptance

\section{Risk Monitoring}

- Expertise

- Controls

- Effectiveness

- Relevance

\section{Independent Variables}

\section{Supply Chain Project}

Performance

- Resilience

- Sustainability

- Adaptability

- Dependability

- Flexibility 


\subsection{METHODOLOGY}

The study adopted a descriptive survey design. The target population of the study was all the completed (566) Supply Chain Projects in Deloitte within the 2013 to 2017 strategic year period. The study used self-structured questionnaires to collect primary data from respondents and the data collected was cleaned, pretested, validated, coded, summarized and analysed using statistical package of SPSS V23. The study findings were presented using bar charts and pie charts

\section{0 RESULTS FINDINGS}

\subsection{Pilot Study Results}

The study conducted pilot study to test reliability and validity of the research instrument. The study used 10 percent of the sampled engineers for pilot testing. Consequently, 10 percent of 56 translated into approximately 6 engineers. The study used random sampling to select 6 engineers of whom were not included in the main survey. The questionnaire was structured in such a way that it collected general information, of the engineers, data on Risk Planning, projects technology, project scheduling and Risk monitoring. With the exception of engineers' general information, other variables were measured as constructs. These variables had several items that measured the same concept or phenomenon.

Thus, this study tested for reliability based on the Cronbach's alpha values for each measurement construct and then for the overall items in the questionnaire. The reliability results for each measurement construct are presented in table 4.1. The result shows that the Cronbach's alpha for Risk Planning constructs is 0.864 with a total of 10 items. This implies that the items included in measuring Risk Planning constructs are indicative of the same underlying disposition. The Cronbach's alpha for project technology, Risk Response, Risk monitoring and Risk Management variables were $0.881,0.876,0.892$ and 0.817 respectively implying that the items in the construct are indicative of the same underlying disposition. The results were as presented in Table 1

The values of the Cronbach's alpha for all measurement constructs is greater than 0.80 value implying that the research instrument is reliable.

\section{Table 1: Reliability Test Results}

\begin{tabular}{lll}
\hline Variables & No. of Items & Cronbach's Score \\
\hline Projects Managers' Competencies & 10 & 0.864 \\
Projects Technology & 11 & 0.881 \\
Projects Schedule & 10 & 0.876 \\
Projects Economic Environment & 12 & 0.892 \\
Projects Risk Management & 10 & 0.817 \\
\hline
\end{tabular}

Further, the study tested for construct validity through in-depth interviews with key informants (civil engineering consulting engineers and civil works claims experts) prior to the of the questionnaire so as to solicit valid concepts. The key informants provided relevant information that was used to modify the questionnaire thereby coming up with constructs that were valid.

\subsection{Effect of Risk Planning on Supply Chain Projects}

\subsubsection{Risk Planning as a Key Factor in Risk Management}


The respondents were asked to indicate whether the Risk Planning were a key factor in Supply Chain Projects. The results were as presented in Table 2.

Table 2: Risk Planning as a Key Factor in Risk Management

\begin{tabular}{lllll}
\hline & \multicolumn{2}{l}{ Frequency } & \multicolumn{2}{l}{ Percentages } \\
\cline { 2 - 5 } & Yes & No & Yes & No \\
\hline Project Managers have conceptual skills & 41 & 1 & 97.6 & 2.4 \\
Projects Managers have technical skill & 42 & 0 & 100 & 0 \\
Project Managers have cost management skills & 35 & 7 & 83.3 & 16.7 \\
Project Managers have motivational skills & 26 & 16 & 61.9 & 38.1 \\
Project Managers have communication skills & 39 & 3 & 92.9 & 7.1 \\
Project Managers have negotiation skills & 38 & 4 & 90.5 & 9.5 \\
Project Managers have people management skills & 33 & 9 & 78.6 & 21.4 \\
Project Managers have project management skills & 40 & 2 & 95.2 & 4.8 \\
\hline
\end{tabular}

From the findings, all the respondents (100\%) agreed that projects managers had technical skills which influencing Supply Chain Projects. In addition, 97.6\% of the respondents indicated that project managers have conceptual skills which influences Supply Chain Projects. Further, 95.2\% of the respondents agreed that project managers have project management skills which influences Supply Chain Projects. Also, 92.9\% of the respondents agreed that project managers have communication skills which influences Supply Chain Projects. These findings concur with Jugdev and Muller (2005) argument that apart from leadership skills, project managers in projects should have communication and motivational skills.

The results also show that $90.5 \%$ of the respondents agreed that project managers have negotiation skills which influences Supply Chain Projects. In addition, $83.3 \%$ of the respondents agreed that project managers have cost management skills which influences Supply Chain Projects. Further, $78.6 \%$ of the engineers agreed that project managers have people management skills which influences Supply Chain Projects. Also, $61.9 \%$ of the respondents agreed that project managers have motivational skills which influences Supply Chain Projects. These findings concur with Spencer and Spencer (2008) argument that managers such as project managers, project coordinators are the drivers of the project and the success of the project depend on their ability to take corrective actions appropriately. The findings also concur with Sarshar, Haigh and Amaratunga (2007) findings that the competence of the project manager has a measurable impact on the performance of the project.

\subsubsection{Importance of Risk Planning in regard to Supply Chain Projects}

The respondents were also requested to indicate the level of importance of Risk Planning in regard to Supply Chain Projects. The results were as presented in Figure 1.

According to the findings, $90.5 \%$ of the respondents indicated that Risk Planning in regard to Supply Chain Projects is very important, $7.1 \%$ indicated its important and $2.4 \%$ indicated it is not important. These findings imply that Risk Planning in regard to Supply Chain Projects are very important. 


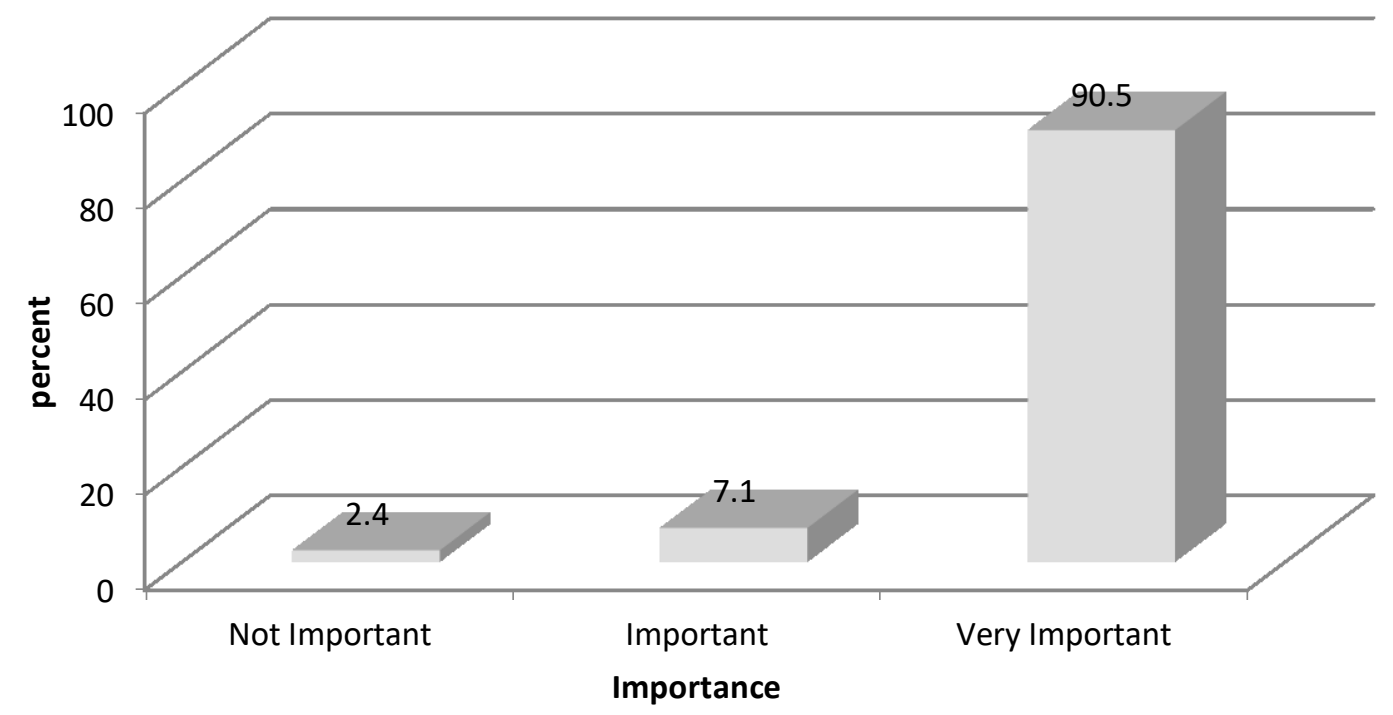

Figure 1: Importance of Risk Planning

\subsubsection{Reasons why Risk Planning are Important}

The respondents were asked to indicate why Risk Planning are important in Supply Chain Projects. The respondents indicated that all projects must be undertaken within acceptable cost to ensure that client and wider public get value for money and resources are not unnecessarily used and hence manager's competencies with regard to project cost are vital. The respondents also indicated that as strategic leaders in management of projects, their roles in cost management become key to fulfilment of project objectives. They further indicated that competency in project management helps to control cost overruns and competent project managers do proper plans devoid of claims during implementation. The competencies of a project manager determine higher understanding of the project and decision making in project implementation and understanding of the contract which influences administration of the contract which finally influencing cost. Also, the resources are limited and therefore it is important for a project manager to get the most out of the resources they are given.

\subsection{Effect of Risk Assessment on Supply Chain Projects}

\subsubsection{Effect of Risk Assessment on Supply Chain Projects}

The respondents were asked to indicate the level of importance of Risk Assessment in Risk Management in supply chain projects. Where 5 was very important, 4 was important, 3 was neutral, 2 was less important and 1 was not important. The results were as presented in Table 3.

From the findings, the respondents indicated with a mean of 4.857 and standard deviation of 0.354 that availability of materials were very important in the Supply Chain Projects. The respondents also indicated that skilled manpower was very important in Supply Chain Projectsas shown by a mean of 4.809 and a standard deviation of 0.397 . The respondents further indicated with a mean of 4.785 and a standard deviation of 0.470 that projects tools and equipment were very important in Supply Chain Projects. In addition, the respondents indicated that technological literacy and awareness were very important in Supply Chain Projects as shown by a mean of 4.714 and a 
standard deviation of 0.673 . Further, the respondents indicated that project team well versed with ICT is very important to Supply Chain Projects as shown by a mean of 4.571 and a standard deviation of 0.500 . These findings agree with DiMaggio (2008) argument that factual and quantitative information should be computerized to speed preparation, collation and assimilation.

Table 3: Effect of Risk Assessment on Supply Chain Projects

\begin{tabular}{lll}
\hline & Mean & Std. Deviation \\
\hline Technological literacy and awareness & 4.714 & .673 \\
Projects tools and equipment & 4.785 & .470 \\
Skilled manpower & 4.809 & .397 \\
Manpower training capacity & 4.357 & .576 \\
Availability of materials & 4.857 & .354 \\
Hauling capacity & 4.261 & .543 \\
Analytical and computational capacity & 4.357 & .790 \\
Technological Innovation & 4.119 & .861 \\
Project team well versed with ICT & 4.571 & .500 \\
\hline
\end{tabular}

Also, the respondents agreed that analytical and computational capacity and manpower training capacity are very important in Supply Chain Projects. This is shown by a mean of 4.357 and a standard deviation of 0.790 . In addition, the respondents agreed that hauling capacity is very important in Supply Chain Projects as indicated by a mean of 4.261 and a standard deviation of 0.543 . The respondents further indicated with a mean of 4.119 and a standard deviation of 0.861 that technological innovation is very important in Supply Chain Projects.

\subsubsection{Other Constructs which are Important to Technology}

The respondents were asked to indicate any other construct considered important to technology. They indicated that other constructs that should be considered include adaptation to new technologies, adoption of contract forms, knowledge in contract law, occupational health and safety, research and development and use of project cost software to determine at an early stage which projects are under quoted or overpriced. According to Polonsky and Waller (2005), sector uses extensive information for decision making process, but does not use much information available elsewhere for example internet and other software products.

\subsubsection{Reasons why Other Constructs are Important to Risk Assessment}

The respondents indicated that other constructs are important to risk assessment because of their importance in activity allocation. New technologies emerging in industries can sometimes result in reduction in cost resulting in savings within projects and a sustainable production. Further, they indicated that other constructs are important to risk assessment because they help in ensuring that the projects are carried out with the required speed and efficiencies and also to be able to determine the latest and most cost-effective trends. These findings agree with Stake (2005) argument that the use of technology improves effectiveness and efficiency in project delivery.

\subsection{Effect of Risk Response on Supply Chain Projects}

\subsubsection{Influence of Risk Response}


International Journal of Supply Chain and

Logistics ISSN 2520-3983 (online)

Vol 3, Issue 3, pp 1 - 23, 2019

www.carijournals.org

The respondents were asked to indicate the extent to which project scheduling influencing Supply Chain Projects in Supply chain projects. The results were as presented in Table 4.

Table 4: Effect of Risk Response

\begin{tabular}{lll}
\hline & Mean & Std. Deviation \\
\hline Schedule development & 4.571 & .500 \\
Schedule crashing & 4.238 & .691 \\
Schedule activity duration & 4.642 & .576 \\
Schedule leads and lags & 4.500 & .671 \\
Activity duration resources & 4.452 & .592 \\
Schedule compression & 4.095 & .957 \\
Sequence of activities & 4.761 & .431 \\
Schedule fast tracking & 4.023 & 1.092 \\
\hline
\end{tabular}

From the findings, the respondents strongly agreed that sequence of activities influences Supply Chain Projects in Supply Chain Projects as shown by a mean of 4.761 and a standard deviation 0.431 . The respondents also strongly agreed with a mean of 4.642 and a standard deviation 0.576 that schedule activity duration influencing Supply Chain Projects in supply chain projects. The respondents further strongly agreed that schedule development influencing Supply Chain Projects in Supply Chain Projects as indicated by a mean of 4.571 and a standard deviation of 0.500 . In addition, the respondents strongly agreed with a mean of 4.500 and a standard deviation of 0.6717 that schedule leads and lags influences Supply Chain Projects in supply chain projects. Further, the respondents agreed that activity duration resources influences Supply Chain Projects as shown by a mean of 4.452 and a standard deviation of 0.592 . Also, the respondents agreed with 4.238 and a standard deviation of 0.691 that schedule crashing influencing Supply Chain Projects in supply chain projects. In addition, the respondents agreed with mean of 4.095 and a standard deviation of 0.957 that schedule compression influencing Supply Chain Projects in supply chain projects. Also, the respondents agreed with a mean of 4.023 and a standard deviation of 1.092 that schedule fast tracking influences Supply Chain Projects in supply chain projects. These findings concur with Thornton Chai and Yusof (2013) argument that to complete the projects on budget and within schedule is an essential benchmark for proprietors and executors.

\subsubsection{Reasons why other Project Scheduling Factors Influences Risk Management}

The respondents indicated that if scheduling is not planned taking cognizance of constraints, the net effect is that machines remain idle and productivity remains low. In addition, if work is scheduled during unfavourable weather condition the performance will be inadequate. Also, schedule decomposition if not done to manageable levels may lead to excessive resource allocation, which has a bearing on Supply Chain Projects. Further, the activities on the critical path influences the completion of the project and therefore special attention should be given to these activities to ensure that they are completed in a timely manner.

\subsection{Effect of Risk monitoring on Supply Chain Projects}

\subsubsection{Effect of Risk monitoring}

The respondents were asked to indicate the extent to which Risk monitoring influences Supply Chain Projects. The results were as presented in Table 5.

\section{Table 5: Effect of Risk monitoring}


International Journal of Supply Chain and

Logistics ISSN 2520-3983 (online)

Vol 3, Issue 3, pp 1 - 23, 2019

www.carijournals.org

\begin{tabular}{lll} 
& Mean & Std. Deviation \\
\hline Gross Domestic Product (GDP) & 4.381 & .763 \\
Cost of relocation of public utilities & 4.785 & .415 \\
Inflation rates & 4.571 & .547 \\
Variation of Cost of labor & 4.238 & .726 \\
Equipment hire rates & 4.214 & .842 \\
Government Debt service ratio & 3.857 & .925 \\
Competing demands for government funds & 4.428 & .737 \\
Unemployment rates & 3.595 & 1.060 \\
Timely exchequer release & 4.976 & .154 \\
Cost of resettlement of project influenced persons & 4.857 & .354 \\
\hline
\end{tabular}

According to the findings, the respondents strongly agreed that timely exchequer release influences Supply Chain Projects in Supply Chain Projects as shown by a mean of 4.976 and standard deviation of 0.154 . The respondent also strongly agreed with a mean of 4.857 and a standard deviation of 0.354 that cost of resettlement of project influenced persons influences Risk Management in supply chain projects.

Also, the respondents strongly agreed with a mean of 4.785 and a standard deviation 0.415 that cost of relocation of public utilities influencing Risk Management in supply chain projects. In addition, they strongly agreed that inflation rates influences Risk Management in Supply Chain Projects as indicated by a mean of 4.571 and standard deviation of 0.547 . Further, the respondents agreed with a mean of 4.428 and a standard deviation of 0.737 that competing demands for government funds influences Risk Management in supply chain projects.

With a mean of 4.381 and a standard deviation of 0.7635 , the respondents agreed that Gross Domestic Product (GDP) influencing Risk Management in supply chain projects. In addition, the respondents agreed that variation of cost of labour influences Risk Management in Supply Chain Projects as indicated by a mean of 4.238 and a standard deviation of 0.726 . Also, the respondents agreed that equipment hire rates influences Risk Management in Supply Chain Projects as indicated by a mean of 4.214 and a standard deviation of 0.842 . These findings agree with Chakravarthy, (1997) that GDP, cost of labour and equipment hire rates influences the Supply Chain Projects. Moreover, the respondents agreed with a mean of 3.857 and a standard deviation of 0.925 that government debt service ratio influences Risk Management in supply chain projects. They also indicted that unemployment rates influences Risk Management in Supply Chain Projects as indicated by a mean of 3.595 and a standard deviation of 1.060. These findings agree with Black and Farias (1997) that changes in macroeconomic factors such as public debt, inflation rate, employment rates, interest rates and foreign exchange rates influences Supply Chain Projects.

\subsubsection{Other Factors of Risk monitoring}

The respondents indicated access to credit facilities by contractors in the region, acquisition of project site especially for supply chains, appreciation of land value hence improved livelihoods, change in legislation, cost of materials sourced locally and foreign, currency exchange rates and inflation index influences Supply Chain Projects.

\subsubsection{Reasons why Other Risk monitoring}


The respondents indicated that between 2013 and 2015, the average cost of variation per project in Deloitte was high due to variation in cost of material, labor and equipment spare parts. In addition, changes in legislation in the middle of contracts administration have financial consequences to the project implementation. Companies whose only challenge is finances make a big difference when they can access credit facilities and complete projects on time. Further, land prices in the country have been rising steadily and at times the cost of land acquisition exceeds the project work cost. These findings agree with Windsor (1995) that access to credit facilities and provision of site of works influencing Risk Management of. In addition, projects in insecure places tend to incur higher cost of implementation since the risks involved are high. The respondent indicated that strong financial institution within the environment will enable project implementers to access ready finances within reasonable times and at reasonable and stable interest rates. Also, with escalation of exchange rates the amounts of local currency spending to cater for foreign currency portion in a project cost goes higher than originally anticipated. These findings agree with (Benton and Lloyd, 2012). That unstable bank lending rates and foreign exchange rates influences Risk Management of projects.

\subsection{Risk Management of projects}

The main objective of the study was to assess the Influence of Risk Management in Supply Chain Projects within Deloitte.

\subsubsection{Importance of Risk Management of Projects}

The respondents were requested to indicate the level of importance of various measures of Risk Management of projects for Deloitte. The results were as presented in Table 6.

Table 6: Importance of Risk Management of Projects

\begin{tabular}{lll}
\hline & Mean & Std. Deviation \\
\hline Scope completion & 4.881 & .327 \\
Timely completion & 4.809 & .397 \\
Customer satisfaction & 4.500 & .594 \\
Quality product & 4.857 & .354 \\
Early Return on Investment & 4.333 & .874 \\
Confidence of Development Partners & 4.690 & .604 \\
Cost minimization & 4.714 & .457 \\
\hline
\end{tabular}

From the findings, the respondents agreed that scope completion was very important in Risk Management of projects as indicated by a mean of 4.881 and a standard deviation 0.327 . The respondents also indicated with a mean of 4.857 and a standard deviation of 0.354 that quality product was very important to Risk Management of projects. Also, the respondents indicated with a mean of 4.809 and a standard deviation of 0.397 that timely completion was very important to Risk Management of projects. In addition, the respondents indicated that cost minimization was very important in Risk Management of projects as indicated by a mean of 4.714 and a standard deviation of 0.457. These findings agree with Enshassi, et al., (2009) that scope completion and cost minimization influences Risk Management.

The respondents agreed that confidence of development partners was very important to Risk Management of projects as indicated with a mean of 4.690 and a standard deviation of 0.457 . The respondents also agreed with a mean of 4.500 and a standard deviation of 0.594 that customer 
satisfaction was very important to Risk Management of projects. In addition, the respondents agreed that early return on investment was important to Risk Management of projects as indicated by a mean of 4.333 and a standard deviation 0.874 . These findings agree with Denini (2009) that confidence of the lending agencies and benefits of early return of investments influences Supply Chain Projects.

\subsubsection{Commitment of Senior Management to Risk Management}

The engineers were asked to indicate whether the senior management of Deloitte is committed to the Supply Chain Projects. The results were as shown in Figure 2.

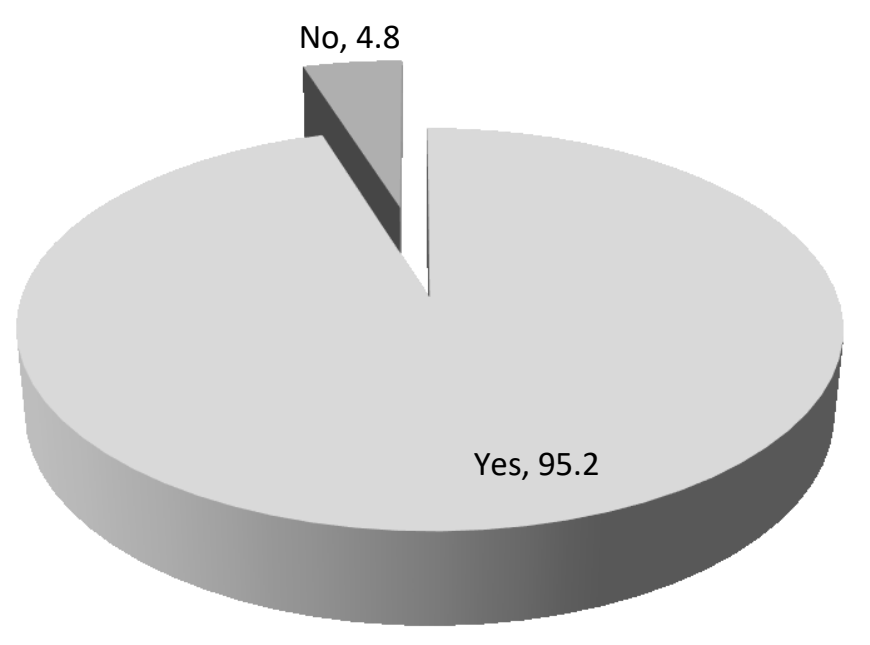

Figure 1: Commitment of Senior Management to Risk Management

According to the findings, $95.2 \%$ of the respondents reported that the senior management of Deloitte is committed to the Supply Chain Projects while $4.8 \%$ disagreed. This implies that the senior management of Deloitte is committed to the Supply Chain Projects. The respondents were also asked to indicate why the senior management of Deloitte is committed to the Supply Chain Projects. From the findings, they indicated that the senior management carries out close monitoring of Risk Management, which is shown by regular review of project cost and implementation. In addition, they indicated that in procurement of contractors the critical basic is quantity cost basic approach. In spite of the challenges that Deloitte faces in executing projects including inadequate funding for, management project cost has always been a key a factor and has always been used in evaluating project success. In addition, the senior management of Deloitte are committed to Supply Chain Projects and this is done by ensuring that projects are closely monitored through monitoring cost vs. progress through monthly and quarterly progress reports and auditing. Also, the Deloitte management is concerned with cost of performance of Supply Chain Projects as a pointer to value for money. These findings agree with Vijayamohanan and Kannan (2009) that inadequate funding and monitoring of ongoing projects influences Supply Chain Projects. However, the respondents indicated that the senior management does not put in place adequate structures to forestall waste and efficiency. Also, cost control in projects starts from planning stage, but most of the projects are hurried due to political demands. 


\subsubsection{Other factors Important to Supply Chain Projects}

The respondents indicated that other factors that are of importance to Supply Chain Projects include achievement of government development goals like vision 2030, budgeting and planning management, cost of relocation, funding intergovernmental treaties, laws and regulations with regards to acquisitions of land and compensation, outsourcing of essential services and political factors may influences the Risk Management. These findings agree with Mansfield, Ogwu, and Doran (2004) that political factors and cost of relocation influencing Supply Chain Projects.

\subsubsection{Reasons why Other Factors are Important to Supply Chain Projects}

The respondents indicated that Risk Management ensures that the money allocated by the government is able to complete the projects without stalling and therefore enabling the government to achieve its goals. In addition, delay causes payment of interest and sometimes default. Engineering consultants are normally required to hasten project delivery which may take long times to deliver if Deloitte's in house team may not be adequate. In addition, they indicated that the cost of project performance will determine whether a project is executed within budget and to the right scope as originally envisaged. These findings agree with Enshassi, Al-Najjar, and Kumaraswamy (2009) that timely Government funding influencing Supply Chain Projects.

\subsection{Regression Analysis}

A multivariate regression analysis was also carried out to determine the relationship between dependent variable and the four independent variables. The regression equation was;

$\mathbf{Y}=\boldsymbol{\beta}_{\mathbf{0}}+\boldsymbol{\beta}_{1} \mathbf{X}_{\mathbf{1}}+\boldsymbol{\beta}_{2} \mathbf{X}_{\mathbf{2}}+\boldsymbol{\beta}_{3} \mathbf{X}_{\mathbf{3}}+\boldsymbol{\beta}_{\mathbf{4}} \mathbf{X}_{4}+\varepsilon$

Whereby; $Y=$ Risk Management of Projects; $X_{1}=$ Risk Planning, $X_{2}=$ Project Technology, $X_{3}=$ Risk Response, $X_{4}=$ Risk monitoring, $\varepsilon=$ Error Term, $\beta_{0}=$ Constant Term and $\beta_{1}, \beta_{2}, \beta_{3}, \beta_{4}=$ Beta Co-efficient

Table 7: Model Summary

\begin{tabular}{llllll}
\hline Model & R & R Square & $\begin{array}{l}\text { Adjusted } \\
\text { Square }\end{array}$ & $\begin{array}{l}\text { R } \\
\text { Est. Error of the } \\
\text { Estimate }\end{array}$ \\
\hline 1 & $0.848^{\mathrm{a}}$ & 0.719 & 0.676 & 0.26884 \\
\hline
\end{tabular}

The R-Squared is the proportion of variance in the dependent variable which can be explained by the independent variables. From the findings, the R-squared in this study was 0.719 which shows that the four independent variables (project manager's competency, Risk Assessment, Risk Responses and Risk monitoring) can explain $71.9 \%$ of the variation in the dependent variable. This clearly shows that other factors not considered in this study explain $28.1 \%$ of the variation in the dependent variable, Risk Management of projects.

Table 8: Analysis of Variance

\begin{tabular}{lllllll}
\hline Model & & Sum of Squares & df & Mean Square & F & Sig. \\
\hline \multirow{4}{*}{1} & Regression & 1.576 & 4 & 0.394 & 5.472 & 0.001 \\
& Residual & 2.664 & 37 & 0.072 & & \\
& Total & 4.240 & 41 & & & \\
\hline
\end{tabular}


The results indicate that the model was significant since the p-value (0.001) was less than 0.05 thus the model is statistically significant in establishing the influence of Risk planning, risk assessment, Risk Response and Risk monitoring on Risk Management in Supply Chain Projects within Deloitte Kenya. Further, the F-calculated (5.472) was found to be more than the F-critical (2.626) which shows that the models were fit in establishing the influence of the four independent variables on the dependent variable.

Table 9: Regression Coefficients

\begin{tabular}{|c|c|c|c|c|c|}
\hline & \multicolumn{2}{|c|}{$\begin{array}{l}\text { Unstandardized } \\
\text { Coefficients }\end{array}$} & \multirow{2}{*}{$\begin{array}{l}\text { Standardized } \\
\text { Coefficients } \\
\text { Beta }\end{array}$} & \multirow[t]{2}{*}{$\mathbf{t}$} & \multirow[t]{2}{*}{ Sig. } \\
\hline & B & Std. Error & & & \\
\hline (Constant) & 3.323 & 0.689 & & 4.823 & 0.000 \\
\hline $\begin{array}{l}\text { Project's manager } \\
\text { competency }\end{array}$ & 0.564 & 0.126 & 0.248 & 4.476 & 0.000 \\
\hline Risk Assessment & 0.426 & 0.113 & 0.226 & 3.770 & 0.010 \\
\hline Risk Response & 0.413 & 0.126 & 0.034 & 3.278 & 0.020 \\
\hline Risk monitoring & 0.464 & 0.112 & 0.198 & 4.143 & 0.001 \\
\hline
\end{tabular}

The regression model was;

$Y=3.323+0.564 X_{1}+0.426 X_{2}+0.413 X_{3}+0.464 X_{4}+\varepsilon$

From the findings, the study found out that there is a positive significant relationship between project's manager competencies and Risk Management of in Supply Chain Projects within Deloitte Kenya with a regression coefficient of 0.564 . This shows that a unit increase in project's manager competency would lead to a 0.564 improvement in the Supply Chain Projects within Deloitte Kenya. The p-value (0.000) was less than the significance level (0.05), hence the relationship was significant. These findings agree with Sarshar, Haigh and Amaratunga (2007) argument that the competence of the project manager has a measurable impact on the performance of the project.

The results also show that there is a positive significant relationship between Risk Assessment and Supply Chain Projects within Deloitte Kenya with a regression coefficient of 0.426 . This shows that a unit increase in Risk Assessment would lead to a 0.426 improvement in Risk Management in Supply Chain Projects within Deloitte Kenya. The relationship was significant as the p-value (0.010) was less than the significance level (0.05). These findings agree with Polonsky and Waller (2005) argument that adoption of technology influences Supply Chain Projects within Deloitte Kenya.

According to the findings, the study found that there is a positive relationship between Risk Response and Risk Management of in Supply Chain Projects within Deloitte Kenya with a regression coefficient of 0.413 . This indicates that a unit increase in project scheduling would lead to a 0.413 improvement in Risk Management in Supply Chain Projects within Deloitte Kenya. The relationship was found to be significant as the p-value (0.020) was less than the significance level (0.05). These findings agree with Thornton Chai and Yusof(2013) argument that "time is essence" and "time is revenue" and that being a way of capturing the relationship between Risk Response to revenue loss. 
Lastly, the study results show that there is a positive significant relationship between Risk monitoring and Risk Management in Supply Chain Projects within Deloitte Kenya as shown by a regression coefficient of 0.464 . This indicates that a unit improvement Risk monitoring would lead to a 0.464 improvement in Risk Management in Supply Chain Projects within Deloitte Kenya. This relationship was significant as the p-value (0.001) was less than of the significance level (0.05). These findings agree with Youker, (2011) argument that some factors within the environment pose greater challenges to projects, management, and organizational structure than others and those factors should form the focus for the management of the projects environment.

These findings infer that project's manager competency was the most significant factor influencing Risk Management in Supply Chain Projectswithin Deloitte Kenya, followed by Risk monitoring, Risk Assessment and Risk Response.

\section{O SUMMARY, CONCLUSION AND RECOMMENDATIONS}

\subsection{Summary of Findings}

\subsubsection{Effect of Risk Planning on Supply chain projects}

The study found that Risk Planning have a positive effect on the Risk Management in Supply Chain Projects within Deloitte. The study also found that projects managers had technical skills which influences Supply chain projects. In addition, the project managers had conceptual skills and project management skills which influences Supply chain projects. Also, the study established that project managers have communication skills, negotiation skills, cost management skills, people management skills and motivational skills, which influences Supply chain projects.

\subsubsection{Effect of Risk Assessment on Supply Chain Projects}

The study found that Risk Assessment has a positive effect on Risk Management in Supply Chain Projects within Deloitte. The study found that materials as well as projects' tools and equipment are very important in Supply Chain Projects. In addition, technological literacy and awareness and a project team well versed with ICT are very important to Supply Chain Projects. Also, the study established that analytical and computational capacity and manpower training capacity are very important in Supply Chain Projects. In addition, the study found that hauling capacity and technological innovation are very important in Supply Chain Projects.

\subsubsection{Effect of Risk Response on Supply Chain Projects}

The study established that Risk Response has a positive effect on Risk Management in Supply Chain Projects within Deloitte. The study revealed that sequence of activities, schedule activity duration and schedule development influences Supply Chain Projects in Supply Chain Projects in supply chain projects. In addition, the study found that schedule leads and lags and activity duration resources influences Supply Chain Projects in supply chain projects. The study further revealed that schedule crashing, schedule compression and schedule fast tracking influences Supply Chain Projects in supply chain projects.

\subsubsection{Effect of Risk monitoring on Supply Chain Projects}

The study established that Risk monitoring has a positive effect on Risk Management in Supply Chain Projects within Deloitte. The study also found that timely exchequer release and cost of resettlement of project influenced persons influences Risk Management in supply chain projects. 
Also, the study found that cost of relocation of public utilities, inflation rates as well as competing demands for government funds influences Risk Management in supply chain projects. The study also revealed that Gross Domestic Product (GDP), variation of cost of labour, equipment hire rates, government debt service ratio and unemployment rates influences Risk Management in supply chain projects.

\subsection{Conclusion}

Based on the study findings, the study concludes that risk planning influences Supply Chain Projects.

\subsection{Recommendations}

The study also recommends that the government of Kenya should revise the current monitory policy governing inflation rates and foreign exchange rates so as to ensure the stability of foreign exchange rates and reduction in inflation rate.

\section{REFERENCES}

Alinaitwe, H., Mwakali, J., \& Hasson, B. (2007). Analysis of accidents on building sites reported in Uganda during 2001-2005. from https://www.irbnet.de/daten/iconda/CIB4931.pdf

Apolot, R., Alinaitwe2, H., \& Tindiwensi, D. (2013). An Investigation into the Causes of Delay and Cost Overrun in Uganda's Public Sector Projects. Retrieved from http://web.usm.my/jcdc/vol18_2_2013/JCDC\%2018(2)\%202013-Art.\%203\%20(3347).pdf

Baccarini, D. (1999, January). The Logical Framework Method for Defining Project Success. Retrieved from https://www.researchgate.net/publication/259268056_The_Logical_Framework_Method_f or_Defining_Project_Success

Bertalanffy, L. v. (1950). An Outline of General System Theory (1950). Retrieved from http://www.isnature.org/Events/2009/Summer/r/Bertalanffy1950-

GST_Outline_SELECT.pdf

Chan, A. P. (2004). Key performance indicators for measuring success. Retrieved from http://www.emeraldinsight.com/doi/abs/10.1108/14635770410532624

Chan, A. P., \& Chan, D. S. (2004). Factors Influencing the Success of a Project. Retrieved from http://chur.chu.edu.tw/bitstream/987654321/39062/2/Factors+Influencing

Cheung, S. O., Suen, H. C., \& Cheung, K. K. (2004). PPMS: a Web-based Project Performance Monitoring System. Retrieved from http://citeseerx.ist.psu.edu/viewdoc/download?doi=10.1.1.459.9739\&rep=rep1\&type=pdf

Cheung, Wong, P. S., \& Yiu, T. W. (2015). the soft power of contracting organisation. Retrieved from

https://books.google.co.ke/books?id=AoEcBgAAQBAJ\&pg=PA38\&dq=cheung+wong+an $\mathrm{d}+$ pang + the + soft + power + of ++ contracting + organisation $\& \mathrm{hl}=$ en $\&$ sa $=X \&$ redir_esc $=\mathrm{y} \# \mathrm{v}=\mathrm{on}$ epage \&q $=$ cheung $\% 20$ wong $\% 20$ and $\% 20$ pang $\% 20$ the $\% 20$ soft $\% 20$ power $\% 20$ of $\% 20 \% 20$ co ntracting $\% 2$ 
International Journal of Supply Chain and

Logistics ISSN 2520-3983 (online)

Vol 3, Issue 3, pp 1 - 23, 2019

www.carijournals.org

Cho, K., Hong, T. o., \& Hyun, C. T. (2009, September). Effect of project characteristics on project performance in projects based on structural equation model. Retrieved from http://www.sciencedirect.com/science/article/pii/S0957417409000736

Chuan, Q. T. (2006). Environmental factors and work performance of project managers in the industry.

Retrieved

from

http://www.sciencedirect.com/science/article/pii/S0263786305000633

Cowell, F. A., \& Gardiner, K. (1999). Welfare weight. Retrieved from http://darp.lse.ac.uk/papersDB/Cowell-Gardiner_(OFT).pdf

Crawford, L., \& Pollack, J. (2004). Hard and soft projects: a framework for analysis. Retrieved from https://opus.lib.uts.edu.au/bitstream/10453/4860/1/2004001481.pdf

Dada, J. O., \& Jagboro, G. .. (2007). An evaluation of the impact of risk on project cost overrun in the Nigerian industry. from http://www.emeraldinsight.com/doi/abs/10.1108/13664380780001092

DOLOI, H., SAWHNEY, A., \& SAWHNEY, A. (2012, October). Structural equation model for investigating factors influencing delay in Indian projects. Retrieved from http://chur.chu.edu.tw/bitstream/987654321/43032/3/103\%E5\%AD\%B8\%E5\%B9\%B4\%E 5\%BA\%A6\%Е5\%9C\%9F\%E6\%9C\%A8\%E5\%B7\%A5\%Е7\%A8\%8B\%E5\%AD\%B8\%E 7\%B3\%BB\%E7\%87\%9F\%Е5\%BB\%BA\%Е7\%AE\%A1\%Е7\%90\%86\%Е7\%B5\%84\%E5 $\% 8 \mathrm{D} \% 9 \mathrm{~A} \% \mathrm{E} 5 \% \mathrm{~A} 3 \% \mathrm{AB} \% \mathrm{E} 7 \% 8 \mathrm{~F} \% \mathrm{AD}-$

2_Structural+equation + model + for + investigating $+\mathrm{f}$

EISENHARDT, K. M. (1985, February). CONTROL: ORGANIZATIONAL AND ECONOMIC APPROACHES. Retrieved from https://business.illinois.edu/josephm/BA549_Fall\%202012/Session\%205/5_Eisenhardt\%2 0(1985).pdf

Eliyahu, G. (1988). Computerized Shop Floor Scheduling. North River Press.

Energy Sector Management Assistance Program (ESMAP). (2010). 2010 Annual Report. Retrieved from http://documents.worldbank.org/curated/en/408911468331735129/pdf/632210AR0ESMA P00Box0361508B0PUBLIC0.pdf

Enhassi, A., Najjar, J. a., \& Kumaraswamy, M. (2009). Delays and cost overruns in the projects in the Gaza Strip. Retrieved from http:/www.emeraldinsight.com/doi/abs/10.1108/13664380910977592

ESMAP/ASTAE Annual Report 2014. (2014). ESMAP/ASTAE Annual Report 2014. Retrieved from http://www.esmap.org/sites/esmap.org/files/DocumentLibrary/ESMAP_ASTAE_Annual_ Report_2014_v2_Optimized.pdf

European Commission. (2012, February). The European Development Fund in a few words. Retrieved from http://www.pedz.uni-mannheim.de/daten/edz-1/gdd/02/fed_en.pdf

Faridi, A. S., \& El-Sayegh, S. M. (2006). Significant factors causing delay in the UAE industry. Retrieved

from https://www.researchgate.net/publication/24077882_Significant_factors_causing_delay_in the_UAE_industry

Frimpong, Y., Oluwoyeb, J., \& Crawford, L. (2003). Causes of delay and cost overruns in of groundwater projects in a developing countries; Ghana as a case study. Retrieved from http://www.tamu.edu/faculty/choudhury/articles/45.pdf

Gido, J., \& Clements, J. P. (2003). successful Project Management,. Soth Western Mason. 
Global environment facility. (2012). Global environment facility ANNUAL PERFORMANCE REPORT 2012. Retrieved from http:/www.thegef.org/sites/default/files/council-meetingdocuments/GEF.ME_.C.44.Inf_.01_Annual_Performance_Report_2012_4.pdf

Hamilton, A. (2004). Handbook of project management procédures. Retrieved from http://www.icevirtuallibrary.com/doi/book/10.1680/hopmp.32583

Hanson, D. N. (2006). CAUSES OF CLIENT DISSATISFACTION IN THE SOUTH AFRICAN BUILDING INDUSTRY AND WAYS OF IMPROVEMENT: THE CONTRACTORS' PERSPECTIVES. Retrieved from http://citeseerx.ist.psu.edu/viewdoc/download?doi=10.1.1.1016.9317\&rep=rep1\&type=pdf

Harvard Business Review. (2015, March). Why senior managers wont collaborate, pp. 75-82.

Huang, X. (2011, March). An Analysis of the Selection of Project Contractor in the Management Process.

Retrieved

from http://www.ccsenet.org/journal/index.php/ijbm/article/viewFile/9709/6959

Juran, J. M., \& Godfrey, A. B. (2010). Juran's quality handbook: The complete guide to performance excellence. New York: Mc Graw Hill.

Juravle, \& Lewis. (2009). The role of championship in the mainstreaming of sustainable investment (SI) - What can we learn from SI pioneers in the United Kingdom? Organization \& Environment. SAGE, 75-98.

Kaliba, C., Muya, M., \& Mumba, K. (2009). Cost escalation and schedule delays in Supply Chain Projectsin Zambia. Retrieved from http://isiarticles.com/bundles/Article/pre/pdf/68267.pdf

Kaming, P. F., Olomolaiye, P. O., Holt, G. D., \& Harris, F. C. (1997, February). Factors influencing time and cost overruns on high-rise projects in Indonesia. Retrieved from https://www.researchgate.net/publication/24077230_Factors_influencing_time_and_cost_ overruns_on_high-rise_projects_in_Indonesia

Katz, D., \& Khan, R. L. (1966). The Social Psychology of Organizations. Retrieved from https://www.tamu.edu/faculty/bergman/katzkahn1978.pdf

Deloitte Annual Report. (2009). Deloitte Annual Report. Environmnetal factors in project implementation, p. 35.

Deloitte Annual Report. (2013). Progress and policies of Deloitte, p. 7.

Deloitte Annual Report. (2014). Deloitte Annual Report. Supply chain implementation constraints, p. 57.

Deloitte Annual Report. (2016). Deloitte Annual Report. Donor funded projects, p. 26.

Kenya Engineer. (2010). Kenya Engineer. Supply chains condition survey in Kenya, p. 13.

Kenya Engineer. (2012). Kenya Engineer. Status and Supply chains, p. 15.

Kerzner, H. (2009). Project Management. New Jersey: John Wiley \& Sons.

Kirsch, I. (1999). Hypnosis and Placebos: Response Expectancy as a Mediator of suggestion effects. Retrieved from http://citeseerx.ist.psu.edu/viewdoc/download?doi=10.1.1.590.8550\&rep=rep1\&type=pdf

Kombo, D. K., \& Tromp, D. L. (2006). Proposal and thesis writing. Makuyu: Paulines Publication Africa.

Koontz, H., \& Weihrich, H. (2009). Essential of Management. Retrieved from https://books.google.co.ke/books?id=s_wzNWdevJoC\&printsec=frontcover\&dq=koontz+a $\mathrm{nd}+$ weihrich $+2009 \& \mathrm{hl}=\mathrm{en} \& \mathrm{sa}=\mathrm{X} \&$ redir_esc $=\mathrm{y} \# \mathrm{v}=$ onepage \&q=koontz$\% 20$ and $\% 20 \mathrm{weihri}$ ch\%202009\&f=false 
Lane, D. A., \& Maxfield, R. (2004). Ontological Uncertainty and innovations. Retrieved from http://samoa.santafe.edu/media/workingpapers/04-06-014.pdf

Ling, F. Y. (2010, May 13). Key determinants of performance of design-bid-build projects in Singapore. $\quad$ Retrieved from http://www.tandfonline.com/doi/full/10.1080/096132103200048497?scroll=top\&needAcce $\mathrm{ss}=$ true

Loosemore, M., \& R, J. R. (2015). Valuing innovation in and infrastructure: Getting clients past a lowest price mentality. Emerald Group Publishing Limited.

Love, P. E., \& Holt, G. D. (2000). business performance measurement: the SPM alternative. Retrieved from http://www.emeraldinsight.com/doi/abs/10.1108/14637150010352417

Magutu, P. O., Nyamwange, S. O., Mbeche, P. I., \& Onsongo, C. O. (2013). An introduction to project management. Nairobi: Lelax Global Ltd.

Mansfield, N., Ugwu, O., \& Daran, T. (1994, November 4). Causes of delay and cost overruns in Nigerian projects. Retrieved from http://www.sciencedirect.com/science/article/pii/0263786394900507

Marasini, R., \& Dawood, N. (2006). Innovative managerial control system (IMCS): an application in precast concrete building products industry. Retrieved from http://www.emeraldinsight.com/doi/abs/10.1108/14714170610710640

Mavondo, F. T. (1999, August). Market Orientation: Scale Invariance and Relationship to Generic Strategies Across Two Countries. Retrieved from https://link.springer.com/article/10.1023/A:1009835515831

Maylor, H. (2003). Project Management. Retrieved from http://www.kvimis.co.in/sites/kvimis.co.in/files/ebook_attachments/Harvey\%20Maylor\%2 0Project\%20Management,3rd_0.pdf

McShane, S. L., \& Glinow, M. A. (2003). Organizational Behavior: Emerging Realities for the Workplace Revolution. New York: McGraw-Hill/.

Meyer, J. (2010, April 30). General Services Administration Streamlines the Procurement of Services. Retrieved from http://calhoun.nps.edu/bitstream/handle/10945/33498/NPS-AM10-065.pdf? sequence=1\&isAllowed $=\mathrm{y}$

Mugenda, O. M., \& Mugenda, A. G. (2003). Research Methods. Nairobi: ACTS PRESS.

Multilateral Investment Guarantee Agency. (2006). Multilateral Investment Guarantee Agency. Retrieved from https://www.miga.org/documents/06arenglish.pdf

Odeyinka, H., \& Oladapo, A. A. (1997, January). The causes and effects of delays on completion cost of housing project in Nigeria. Retrieved from https://www.researchgate.net/publication/249643683_The_causes_and_effects_of_delays on_completion_cost_of_housing_project_in_Nigeria

Ouchi, W.. $\bar{G}$. (1979, September 9). A Conceptual Framework for the Design of Organizational Control Mechanisms. Retrieved from https://business.illinois.edu/josephm/BA545_Fall\%202011/S3/Ouchi\%20(1979).pdf

Oya Icmeli Tukel, W. O. (1998). Analysis of the characteristics of projects in diverse industries. Retrieved from http://www.sciencedirect.com/science/article/pii/S0272696397000168

PARK, N., PETERSON, C., \& SELIGMAN, M. E. (2004). STRENGTHS OF CHARACTER AND WELL-BEING. Retrieved from http://www.viacharacter.org/blog/wpcontent/uploads/2013/12/Character-strengths-well-being-Park-Peterson-Seligman-2004.pdf 
Peterson. (2004). Cultural Intelligence - A guide to working with people from other culture. Maine: Intercultural Press .

Reschke, H., \& Schelle, H. (2012). Dimension of project management: fundamentals, techniques, organisation applications. Retrieved from https://books.google.co.ke/books?id=9F3yCAAAQBAJ\&printsec=frontcover\&dq=Reschk $\mathrm{e}+$ and + Schelle $+(2012)+$ Dimensions + of + Project + Management\&hl $=$ en\&sa $=$ X\&redir_esc $=y$ $\# \mathrm{v}=$ onepage\&q\&f$=$ false

ROGERS, E. M. (1995). DIFFUSION OF INNOVATIONS. Retrieved from https://www.d.umn.edu/ /rochfor/ireland/dif-of-in-ch06.pdf

Shahrzad Khosravi, H. A. (2011). A Success Measurement Model for Projects. Retrieved from http:/www.ipedr.com/vol11/36-W00014.pdf

THE KENYA SUPPLY CHAINS ACT. (2007). THE KENYA SUPPLY CHAINS ACT. Retrieved from http://kenyalaw.org/lex/rest//db/kenyalex/Kenya/Legislation/English/Amendment\%20Acts/ No.\%202\%20of\%202007.pdf

Tiwana, A. (2009, June). Governance-Knowledge Fit in Systems Development Projects. Retrieved from https://www.researchgate.net/publication/220079649_GovernanceKnowledge_Fit_in_Systems_Development_Projects

Toor, S.-U.-R., \& Ogunlaga, S. O. (2009). professionals' perception of critical success factors for large-scale projects. Retrieved from http://www.emeraldinsight.com/doi/abs/10.1108/14714170910950803

UNRWA. (2014). the harmonized results report 2014. Retrieved from https://www.unrwa.org/sites/default/files/harmonized_results_report_2014_0.pdf

Vandevoorde, I. S., \& Vanhoucke, P. D. (2006, January 19). New Grounds:Time Dimension in Earned Value Management. from http://www.earnedschedule.com/Docs/New\%20Grounds\%20PMB\%202006\%20Vandevoo rde.pdf

Vanhoucke, M., \& Vandevoorde. (2007-2008). Measuring the accuracy of earned value/earned schedule forecasting predictors. Retrieved from http://discovery.ucl.ac.uk/1506256/

Weil, D. N. (2013). Economic growth. Retrieved from https://books.google.co.ke/books?id=p79JDAAAQBAJ\&pg=PR2\&dq=weil $+2013+$ econo mic + growth+international+edition \&hl $=$ en\&sa $=X \&$ redir_esc $=y \# v=$ onepage \&q $=$ weil $\% 2020$ $13 \% 20$ economic\%20growth\%20international\%20edition $\& \mathrm{f}=$ false 